\title{
ANALISIS FAKTOR-FAKTOR PENYEBAB PERCERAIAN BERDASARKAN KEPUTUSAN PENGADILAN NEGERI BALIGE TAHUN 2017
}

\author{
Bernhardt Siburian \\ Institut Agama Kristen Negeri Tarutung \\ siburian.bernhardt@gmail.com
}

\begin{abstract}
The objective of this research is to know dominant factors which evoke Christian married couple divorce based on finding of Balige State Court in 2107 in efforts prevention by church for the people of Toba Samosir. This research use descriptive qualitative approach with documents analysis method. Data analysis carried out by doing interpretation the result of qualitative data analysis, after act of ranking grades and percentage be done. The act of data analysis is done since team of researcher start doing data classification (coding) within effective reading. Data interpretation is done by two stages, first interpretation of each data item and second, interpretation of all data. The result of data interpretation indicate insufficient family financial factor occupy in the highest sequence, which causing constantly dispute and no hope for living in harmonious anymore. The result of this research, then, posses coherence with Chapter 19 Government Regulation No. 9/1975 regarding Law Implementation No. 1/1974 and base theories of married couple experts.
\end{abstract}

Keywords: analysis, divorce, merried couple, state court decision

\begin{abstract}
Abstrak
Penelitian ini bertujuan untuk mengetahui faktor-faktor dominan yang menyebabkan perceraian berdasarkan Keputusan Pengadilan Negeri Balige tahun 2017 dalam upaya penanggulangan yang dilakukan oleh gereja bagi masyarakat Toba Samosir. Penelitian ini menggunakan pendekatan deskriptif kualitatif dengan metode analisis dokumen. Analisis data dilakukan dengan menginterpretasikan hasil analisis data kualitatif, setelah penyusunan persentase dan ranking dilakukan. Tindakan analisis data dilakukan sejak para peneliti mulai melakukan klasifikasi (pengkodean) melalui pembacaan efektif dokumen. Kemudian peneliti akan melakukan interpretasi data dengan dua tahap, yaitu interpretasi data setiap item dan interpretasi keseluruhan data. Hasil interpretasi analisis data menunjukkan bahwa faktor keuangan yang tidak mencukupi menempati urutan tertinggi, yang menyebabkan pertengkaran yang terus-menerus dan tidak ada harapan hidup rukun lagi. Dengan demikian hasil penelitian ini memiliki koherensi dengan Pasal 19 Peraturan Pemerintah Nomor 9 tahun 1975 tentang Pelaksanaan Undang-undang Nomor 1 Tahun 1974 dan juga landasan teori-teori para ahli.
\end{abstract}

Kata Kunci: analisis, perceraian, pasutri, keputusan, pengadilan 


\section{Pendahuluan}

Berdasarkan hasil wawancara dengan Panitera Muda Perdata Pengadilan Negeri Balige $^{1}$, tim penelti mendengar dan menerima informasi tentang meningkatnya kasus perceraian 'pasangan suami isteri'2 Kristen yang didaftarkan dan yang telah diputuskan oleh Pengadilan Negeri Balige Kabupaten Toba Propinsi Sumatera Utara. Berikut ini adalah rekapitulasi jumlah perceraian pasutri Kristen yang diputuskan di Pengadilan Negeri Balige tahun $2015 \mathrm{~s} / \mathrm{d} 2018$ :

\section{Rekapitulasi Jumlah Kasus Perceraian Pasutri Kristen yang Diputuskan di Pengadilan Negeri Balige Kabupaten Toba-Samosir} Tahun $2015 \mathrm{~s} / \mathrm{d} 2018$

\begin{tabular}{|c|c|c|c|}
\hline \multirow{2}{*}{ Tahun } & \multicolumn{2}{|c|}{ Status Kasus } & \multirow{2}{*}{ Keterangan } \\
\cline { 2 - 3 } & Terdaftar & Putusan & \\
\hline$(1)$ & $(2)$ & $(3)$ & $(4)$ \\
\hline \hline 2015 & 20 & 20 & - \\
\hline 2016 & 21 & 21 & naik 0,05\% \\
\hline 2017 & 31 & 31 & naik 47,61\% \\
\hline 2018 & 10 & - & - \\
\hline
\end{tabular}

Bagi para pegawai di lingkup Pengadilan Negeri Balige, situasi meningkatnya kasus perceraian pasutri Kristen pada tahun 2017 sebesar 47,61 \% dari tahun sebelumya dianggap cukup signifikan. ${ }^{3}$ Tidak hanya dari segi jumlah angka, tetapi oleh sebab mereka adalah penganut agama Kristen, bahwa setiap pasangan yang sedang melangsungkan acara pernikahan menyatakan diri dan berikrar (menyaksikan iman) bersedia mengikuti teladan Yesus Kristus dalam mengasihi dan melaksanakan ajaran serta firman-Nya dalam kehidupan pasutri, dalam hal ini, secara khusus menyatakan diri pantang bercerai hingga kematian yang memisahkan setiap pasangan pasutri Kristen. Hal tersebutlah yang menjadi latar belakang pertama bagi tim peneliti untuk mencoba menelusurinya melalui proses penelitian

Selain itu, alasan kedua, menurut - peneliti setuju dengan - para pegawai di lingkup Pengadilan Negeri Balige, situasi tersebut dipandang identik dengan teori gunung es; bahwa kasus perceraian pasutri Kristen yang diputuskan Pengadilan Negeri Balige adalah hal-hal yang hanya nampak di bagian permukaan, namun fenomenanya dimungkinkan masih menumpuk di aras bawah dan hanya menunggu waktu saja untuk muncul ke permukaan, yang salah satu indikasinya nampak pada persentase kenaikan kasus tersebut pada tahun 2017 sebesar $47,61 \%$.

Oleh kedua latar belakang masalah di atas, ketiga, tim peneliti yang juga memberi perhatian terhadap studi teologi praktika, merasakan bahwa agaknya dibutuhkan beberapa kontribusi pada materi pembelajaran pembelajaran di Perguruan Tinggi (PT) Institut Agama Kristen Negeri (IAKN) Tarutung sehubungan dengan meningkatnya angka kasus perceraian pasutri Kristen tersebut, dengan menggunakan hasil analisis faktor-faktor penyebabnya.

1 Aser Limbong, wawancara oleh Tim Peneliti, Tarutung, Indonesia, 04 Pebruari 2018.

2 Selanjutnya disebut 'pasutri'.

${ }^{3}$ Penelitian ini tidak membutuhkan skala perbandingan antara jumlah rumahtangga Kristen dengan tingkat perceraian rumahtangga Kristen di Kabupaten Toba-Samosir. Berdasarkan jumlah total putusan kasus pidana-perdata di PN Balige Kabupaten Toba-Samosir yaitu 91 putusan, dengan demikian kasus perdata perceraian ada sebanyak $30 \%$. Angka tersebut sudah dapat dianggap berada dalam kisaran yang cukup mengkhawatirkan. 
Kontribusi yang dimaksud dapat saja dilakukan pada lingkup materi pembelajaran dan aplikasinya (mis. pada matakuliah Kataketika, Konseling Pastoral, Etika Kristen, Teologi Perjanjian Baru dan Teologi Perjanjian Lama) dan atau dapat saja pada sistem (pola) kinerja para pengerja gereja (mis. pada matakuliah Administrasi dan Manajemen Gereja). Kontribusi tersebut tentu saja diharapkan menjadi upaya dalam merumuskan daya antisipasi dini atau tanggap dini dalam menghadapi konflik pasutri Kristen, sebelum salah satu pihak dari pasangan pasutri melakukan tindak Kekerasan Dalam Rumah Tangga (KDRT) dan atau meneruskan atau mengajukan permohonan cerai di pengadilan.

Dari banyaknya jumlah gugatan cerai tersebut secara gamblang para peneliti dapat memahami bahwa motivasi dan atau juga latar belakang masing-masing pasutri tersebut dalam melangsungkan pernikahan masih jauh dari harapan mereka masing-masing sehubungan dengan janji yang telah mereka ikrarkan pada saat acara pemberkatan pernikahan. Dapat pula dimungkinkan bahwa masing-masing pihak pasutri tersebut lupa akan janji pernikahan mereka sendiri, atau betapa kuatnya godaan yang mengguncang dan melanda salah satu atau kedua pihak setiap pasutri. Oleh sebab itulah, sebelum peneliti terjebak dalam berbagai asumsi yang mengundang dan mengandung unsur multi-tafsir dari pihak peneliti atau pun pembaca dan juga pihak lainnya, maka tim peneliti merumuskan penelitian ini dengan judul: "Analisis Faktor-faktor Penyebab Perceraian Berdasarkan Keputusan Pengadilan Negeri Balige Tahun 2017 Dalam Upaya Penanggulangan Yang Dilakukan Oleh Gereja Bagi Masyarakat Toba Samosir".

\section{Metode Penelitian}

Penelitian ini menggunakan pendekatan kualitatif deskriptif dengan metode analisis dokumen. Analisis data dilakukan dengan menginterpretasikan hasil analisis data kualitatif. Data penelitian ini adalah dokumen Berita Acara dan Keputusan Pengadilan Negeri Balige Kabupaten Toba Samosir. Oleh sebab data penelitian ini adalah kompilasi dokumen, tindakan analisis data dilakukan sejak para peneliti mulai melakukan klasifikasi (pengkodean) melalui pembacaan dokumen secara efektif dan efisien. Selanjutnya peneliti akan menganalisis faktor-faktor dominan data dengan membuat persentase dan ranking. Kemudian peneliti akan melakukan interpretasi data dengan dua tahap, pertama, interpretasi data setiap item, dan kedua, interpretasi keseluruhan data. Dari 31 kasus perdata perceraian tersebut terdapat tiga pasutri (atau salah seorang pasutri yang menjadi penggugat) yang membatalkan dan menarik gugatannya, 15 kasus perdata perceraian naik banding ke Pengadilan Tinggi di Medan dan 12 kasus yang diputuskan cerai di PN Balige. Dengan demikian data penelitian ini adalah masing-masing 12 dokumen Berita Acara dan Keputusan kasus pedata perceraian pasutri saja.

\section{Hasil dan Pembahasan}

Hasil penelitian menyimpulkan bahwa: [1] Perselisihan antara suami dan istri terus menerus terjadi perselisihan dan pertengkaran dan tidak ada harapan akan hidup rukun lagi dalam rumah tangga, yaitu 38,71 \% atau 12 item. Pihak yang memulai pertengkaran paling banyak adalah pihak suami yaitu sebesar $75 \%$ (delapan item); sedangkan pihak isteri sebanyak $25 \%$ (empat item). [2] Faktor tertinggi kedua adalah salah satu pihak melakukan kekejaman atau penganiayaan berat yang membahayakan terhadap pihak lain dan juga tindakan menghina pasangan atau mertua atau anggota keluarga pasangannya, yang mencapai angka 25,81 \% (delapan item). [3] Faktor tertinggi ketiga (19,35 \%, enam item) adalah salah satu pihak berbuat zina/pemabuk/pecandu narkoba/penjudi. [4] Faktor tertinggi keempat salah satu pihak pasutri oleh sebab salah satu pihak pasutri meninggalkan 
atau menelantarkan pasangannya, yang mencapai angka $9.68 \%$ (tiga item). [5] Yang kelima adalah salah satu pihak pasutri mengalami cacat badan atau mengidap penyakit, yaitu sebanyak $6,45 \%$ (dua item).

Hasil interpretasi analisis data menunjukkan bahwa faktor keuangan yang tidak mencukupi menempati urutan tertinggi, termasuk di dalamnya malas mencari nafkah, tidak mau menafkahi keluarga, pekerjaan tidak menetap atau pengangguran, yaitu empat item. Faktor penyebab perceraian yang menempati urutan tertinggi kedua adalah faktor melakukan zina dan mengabaikan tanggung jawab, masing-masing tiga item. Cukup disayangkan, pasutri yang rumah tangganya mengalami situasi keuangan tidak mencukupi, justru juga melakukan zina (satu item), mabuk-mabukan (satu item), pecandu narkoba (satu item), perjudian (satu item). Faktor tertinggi ketiga adalah mabuk-mabukan, judi dan mengidap suatu penyakit (masing-masing dua item) dan faktor keempat adalah pengguna narkoba (satu item). Sedangkan yang tidak membutuhkan penjelasan tambahan adalah faktor tunggal penyakit (dua item). Dengan demikian hasil penelitian ini memiliki koherensi dengan Pasal 19 Peraturan Pemerintah Nomor 9 tahun 1975 tentang Pelaksanaan Undangundang Nomor 1 Tahun 1974 dan juga landasan teori-teori para ahli.

\section{Persentasi dan Rangking Faktor-faktor Penyebab Perceraian pada Putusan Perdata Perceraian Tahun 2017 Pengadilan Negeri Balige Kabupaten Toba Samosir}

\begin{tabular}{|c|l|c|c|}
\hline No. & \multicolumn{1}{|c|}{$\begin{array}{c}\text { Item Faktor-faktor } \\
\text { Penyebab Perceraian }\end{array}$} & $\begin{array}{c}\text { Jumlah } \\
\text { Item }\end{array}$ & $\begin{array}{c}\text { Persentase } \\
(\%)\end{array}$ \\
\hline$(1)$ & \multicolumn{1}{|c|}{$(2)$} & $(3)$ & $(4)$ \\
\hline \hline 1 & Berbuat zina/pemabuk/pecandu narkoba/penjudi & 6 & $19,35 \%$ \\
\hline 2 & Meninggalkan pasangan dua tahun berturut-turut & 3 & $9.68 \%$ \\
\hline 3 & Mendapat hukuman penjara lima tahun/lebih berat & 0 & $0 \%$ \\
\hline 4 & Melakukan kekejaman atau penganiayaan berat & 8 & $25,81 \%$ \\
\hline 5 & Mengalami cacat badan atau mengidap penyakit & 2 & $6,45 \%$ \\
\hline 6 & Terjadi pertengkaran, tidak ada harapan hidup rukun lagi & 12 & $38,71 \%$ \\
\hline \multicolumn{2}{r|}{ Jumlah skor } & 31 & $100 \%$ \\
\hline
\end{tabular}

Berdasarkan hasil interpretasi dan analisis dukumen Berita Acara Persidangan dan Putusan Perdata Perceraian Tahun 2017 pada Pengadilan Negeri Balige Kabupaten Toba Samosir pada semua item dapat ditemukan: pertama, secara umum, salah satu pihak pasutri yang mengajukan gugatan cerai di Pengadilan Negeri Balige Kabupaten Toba Samosir adalah dimulai dengan adanya perselisihan atau pertengkaran (komunikasi buruk), ditambah dengan dorongan yang kuat bahwa tidak ada harapan akan hidup rukun lagi dalam rumah tangganya. Hal percekcokan inilah yang paling dominan diajukan pihak penggugat agar majelis hakim Pengadilan Negeri Balige Kabupaten Toba Samosir dapat segera memutus perkara dan sekaligus agar pihak penggugat dapat memenangkan perkara. Ini ditandai dengan jumlah item terbanyak yaitu 12 item (100\%).

Kedua, salah satu pihak pasutri tidak terbuka bahkan terkesan menutup-nutupi akan situasi diri terhadap pasangannya sehubungan dengan tindakan penelantaran dan mengabaikan tanggungjawab (termasuk di dalamnya keuangan yang tidak mencukupi, malas bekerja, tidak mau menafkahi dan penyakit yang diderita). Salah satu pihak pasutri tidak mengetahui dan tidak memahami dan juga perduli akan tujuan ideal pernikahan serta tidak perduli akan peran, tugas dan tanggungjawab masing-masing pihak sebagai suami/isteri. Hal ini ditandai dengan sikap dan karakter buruk yang dimiliki dan juga ketidakperdulian akan perasaan pasangannya yang menjadi pokok isi gugatan pasangannya 
tersebut. Sikap ketidakperdulian tersebutlah yang menguatkan dorongan bagi pasangannya untuk tetap bertahan menuntut cerai.

Bahwa secara umum, dorongan gugatan perceraian pasutri datang dari dalam rumahtangga pasutri itu sendiri; bukan dari pihak di luar rumahtangga pasutri. Dalam hal ini majelis hakim memandang dan menetapkan bahwa salah satu pihak pasutri yang tidak dapat memenuhi tuntutan UU Perkawinan No. 1 Tahun 1974 Pasal 39, Peraturan Pemerintah No. 9 Tahun 1975 Pasal 19 dan juga UU No. 1 Tahun 1974 tentang Perkawinan.

\section{Ranking Faktor-faktor Awal Penyebab Perceraian pada \\ Putusan Perdata Perceraian Tahun 2017 \\ Pengadilan Negeri Balige Kabupaten Toba Samosir}

\begin{tabular}{|c|c|c|c|c|}
\hline $\begin{array}{l}\mathrm{N} \\
\mathrm{o}\end{array}$ & $\begin{array}{c}\text { Item Faktor-faktor } \\
\text { Awal Penyebab Perceraian }\end{array}$ & $\begin{array}{l}\text { Nomor } \\
\text { Item }\end{array}$ & $\begin{array}{c}\text { Jumla } \\
\text { h } \\
\text { Item }\end{array}$ & $\begin{array}{c}\text { Rangki } \\
\text { ng }\end{array}$ \\
\hline$(1)$ & $(2)$ & $(3)$ & $(4)$ & $(5)$ \\
\hline 1 & Melakukan zina & $44,5,6$ & 3 & 2 \\
\hline 2 & Mabuk-mabukan & 2,6 & 2 & 3 \\
\hline 3 & Judi & 2,9 & 2 & 3 \\
\hline 4 & Pecandu narkoba & 6 & 1 & 4 \\
\hline 5 & Penyakit ${ }^{4}$ & 1,10 & 2 & 3 \\
\hline 6 & Keuangan yang tidak mencukupi ${ }^{5}$ & $3,6,9,12$ & 4 & 1 \\
\hline 7 & Mengabaikan tanggungjawab ${ }^{6}$ & $7,8,11$ & 3 & 2 \\
\hline
\end{tabular}

Salah satu pihak pasutri dalam penelitian ini yang mengajukan gugatan cerai, terlebih dahulu diawali dengan terjadinya perselisihan atau pertengkaran. Setiap pertengkaran tidak dapat diselesaikan dengan baik. Tidak ada yang mengalah di antara salah satu pihak pasutri. Sementara pihak yang menjadi korban kekerasan dan ketidakperdulian penelantaran merasa bahwa dirinya sudah tidak sanggup lagi menahan kesabaran, sebab kesalahan dan tindak kekerasan terus-menerus dilakukan atau diulangulang oleh pasangannya.

Sehubungan dengan pokok perselisihan dan pertengkaran tersebut, maka dalam penyusunan modul penanggulangan yang akan dikembangkan sangat perlu untuk memuat materi bimbingan tentang pengendalian diri dalam menahan emosi dan juga tentang komunikasi yang memadai dalam masa berpacaran atau dalam pelaksanaan bimbingan pranikah. Sedangkan mengenai adanya penyakit yang diidap salah satu pihak pasutri baik penyakit medis maupun unsur psikologis (mis. impotensi), maka pada modul yang akan dikembangkan kemudian perlu dimasukkan tentang perlunya dorongan dan dukungan dari pasangannya untuk mendampingi pasangannya tersebut dalam menjalani terapi medis dan psikologis, secara khusus tentang sikap penerimaan situasi dan keadaan pasangannya yang sedang mengidap penyakit tersebut atas nama dan di dalam cinta kasih yang murni yang datang dari TUHAN.

4 Hal ini mencakup: disfungsi anggota tubuh, misalnya gangguang fungsi seksual, yang mengakibatkan salah satu pihak tidak dapat menjalankan kewajibannya sebagai suami atau istri.

${ }^{5}$ Hal ini mencakup: malas mencari nafkah, tidak mau menafkahi keluarga, pekerjaan tidak menetap dan pengangguran.

${ }^{6} \mathrm{Hal}$ ini mencakup: pasangan sering mengabaikan kewajiban rumahtangga dan anak (seperti jarang pulang ke rumah, tidak adanya kedekatan emosional dengan anak dan pasangan), George Levinger dan Oliver C. Moles, Divorce and Separation, Context, Causes and Consequences, New York: Bank Books, 1984, hlm. 78. 
Sekalipun semua pasutri menjalani proses dan prosesi adat dalam acara pernikahan, kedua belah pihak pasutri tidak menemukan solusi atau usaha pendamaian atau rujuk kembali. Ada kesan bahwa adat tidak digunakan menjadi jalur mediasi demi pendamaian rumahtangga pasutri yang sedang menghadapi konflik. Padahal ada pihak-pihak di dalam jalur adat yang berkompeten manangani konflik rumahtangga pasutri dan bahwa seluruh biaya pernikahan didominasi oleh beban adat.

Bahkan ada beberapa pasutri yang kedua pihak pasutri tersebut bekerja sebagai ASN. Artinya, bahwa standar pendidikan dan standar penghasilan dianggap telah memadai, bahkan sifat, sikap dan karakter seorang ASN seyogianya berada pada jalur yang baik dan ideal. Namun hal itu pun tidak dapat membendung kuatnya dorongan gugatan cerai yang diajukan oleh salah satu pihak pasutri.

Pihak Pengadilan Negeri Balige Kabupaten Toba Samosir dalam hal ini majelis hakim juga telah mengupayakan agar setiap pasutri yang menjalani sidang perkara perceraian dapat rujuk atau berdamai kembali, sebagaimana juga yang dilakukan terhadap pihak-pihak yang bersengketa pada kasus perdata perselisihan ringan (salah paham tingkat rendah). Dalam upaya agar rumah tangga pasutri tersebut dapat rujuk kembali, majelis hakim menunjuk salah seorang hakim anggota persidangan untuk melakukan mediasi (diatur dalam Perma No. 1 Tahun 2016 tentang Prosedur Mediasi di Pengadilan). Dalam hal ini, pihak Pengadilan Negeri Balige Kabupaten Toba Samosir melakukan pemanggilan secara resmi dan tercatat kepada masing-masing pihak dan kemudian dipertemukan (atau perwakilannya) untuk melakukan mediasi. Mediasi ini bahkan dilakukan dua atau tiga kali pertemuan, dengan harapan agar rumahtangga pasutri tersebut dapat rujuk dan berdamai kembali. Dari 31 kasus perceraian sebagaimana yang disebut pada bagian 4.1. di atas, terdapat tiga pasutri (atau salah seorang pasutri yang menjadi penggugat) yang menarik dan membatalkan gugatannya. Demikianlah upaya mediasi yang dilakukan oleh pihak Pengadilan Negeri Balige Kabupaten Toba Samosir.

Sementara itu, dari 12 dokumen kasus perdata perceraian pasutri tahun 2017 pada Pengadilan Negeri Balige Kabupaten Toba Samosir, hanya satu pasutri yang melibatkan pihak pelayan rohani (pastor, pendeta, penatua, imam kaum penghayat kepercayaan) dalam upaya pendamaian rumahtangga pasutri yang bersengketa. Sedangkan 11 pasutri lainnya sama sekali tidak meminta bantuan pelayan rohani dalam menemukan solusi untuk persoalan rumahtangga pasutri yang bersengketa. Usaha pendamaian yang dilakukan oleh pihak pelayan rohani untuk satu pasutri tersebut pun tidak membuahkan hasil, bahwa pasutri tersebut akhirnya bercerai.

Ada kesan bahwa sekalipun pihak isteri yang menjadi tulang-punggung keluarga, pihak isteri masih dapat sabar dan toleran terhadap suami walaupun suami memiliki penghasilan yang belum memadai. Namun oleh sebab sikap dan karakter pihak suami yang melakukan tindak kekerasan, pihak isteri pun mengajukan gugatan cerai.

Pada dasarnya setiap pasutri yang bersengketa sudah tidak tinggal bersama dalam satu rumah lagi (tidak satu meja dan tidak satu ranjang), bahwa mereka sudah berpisah sekian waktu lamanya baru kemudian salah satu pihak mengajukan gugatan perceraian. Situasi tidak tinggal bersama ini terjadi baik oleh sebab salah satu pihak tidak mau menjadi korban tindak kekerasan atau penganiayaan atau tidak tahan lagi melihat sikap dan karakter buruk pasangannya.

Dari dua belas dokumen putusan perdata perceraian tersebut, peneliti menyimpulkan bahwa hanya dua orang dari pihak isteri pasutri yang menjadi pemicu terjadinya pertengkaran, secara khusus untuk faktor "mengabaikan tanggung jawab" (yaitu sebanyak tiga item), itu pun, salah satunya diduga mengidap suatu penyakit (mungkin mental disorder) dan satunya oleh sebab yang tidak dapat diketahui. Sedangkan seluruh item 
faktor-faktor awal lainnya yang memicu terjadinya pertengkaran yang menyebabkan perceraian pasutri tersebut adalah dilakukan oleh pihak suami.

Sehubungan dengan judul penelitian siklus pertama ini dikaitkan dengan upaya gereja dalam penanggulangan percerian pasutri, para peneliti mengusulkan untuk menyusun modul bagi pelayan gereja dalam melakukan bimbingan pra-nikah. Modul tersebut direncanakan akan memuat tentang pembahasan antara lain: (a) beberapa jenis kasus perceraian pasutri Kristen, (b) motivasi, harapan dan persiapan menjadi pasutri Kristen, (c) tanggung jawab diri menjadi pasutri Kristen dalam keluarga, (d) pembinaan terikat pasutri muda Kristen (usia lima tahun pertama), yaitu wajib menjadi anggota komunitas atau persekutuan masing-masing untuk kaum bapak atau ibu usia lima tahun pertama. Poin terakhir ini akan membantu para pelayan gereja melaksanakan tanggungjawab dan kewajibannya untuk cepat dan tanggap dini mendengar apabila pasutri tersebut sedang menghadapi konflik rumah tangga, serta melakukan tugas penatalayanannya. Poin ini juga sangat menolong pasutri Kristen itu sendiri untuk mendapatkan haknya dalam memperoleh penatalayanan dari pihak gereja.

\section{Kesimpulan}

Dari keterangan hasil dan pembahasan di atas maka dapat ditarik beberapa pokok kesimpulan, yaitu:

1. Bahwa perceraian pasutri pada dasarnya dipicu oleh sifat, sikap dan karakter buruk salah satu atau kedua pihak pasutri, secara khusus mengenai etika dan moral, menutupnutupi situasi diri dan penyakit. Hal inilah yang memicu perselisihan dan pertengkaran sekaligus pula menjadi dasar bagi pasangannya mengajukan gugatan cerai. Ditambah lagi, tindak kekerasan dan pengaiayaan berat yang dilakukan oleh salah satu pihak pasutri, termasuk tindakan penelantaran dan ketidakperdulian terhadap perasaan dan diri pasangannya, itulah yang menguatkan dorongan pasangannya untuk tetap bertahan menuntut cerai. Dengan demikian hasil penelitian ini memiliki koherensi dengan Pasal 19 Peraturan Pemerintah Nomor 9 tahun 1975 tentang Pelaksanaan Undang-undang Nomor 1 Tahun 1974.

2. Persiapan, komitmen dan konsistensi pada janji pernikahan pasutri Kristen dalam menghadapi dan menjalani kehidupan pernikahannya masing-masing kurang atau sangat tidak memadai. Situasinya seolah-olah bahwa beberapa keluarga di antara pasutri Kristen yang bercerai tersebut agaknya terkesan "asal menikah" atau "salah memilih pasangan" (cinta buta). Indikasinya dapat dilihat bahwa dua diantara duabelas pasutri yang sudah diputus cerai oleh hakim (selain yang menarik gugatan) terlebih dahulu menghadapi situasi hamil sebelum menikah. Indikasi kedua yang menguatkan interpretasi tersebut adalah bahwa salah satu pihak dari keduabelas pasutri yang sudah diputus cerai oleh hakim (selain yang menarik gugatan), memiliki karakter buruk dan sulit untuk diubah (bertobat). Majelis hakim-lah oleh pertimbangan mereka yang paling mengetahui karakter salah satu pihak pasutri yang sungguh-sungguh atau pun yang berpura-pura mempertahankan pernikahan mereka atau pun yang sudah pasrah dengan masing-masing pasangannya sendiri dalam memenangkan gugatan cerai rumahtangga mereka sendiri.

3. Tentu saja pihak gereja tidak dapat menerima dan dengan tegas menolak putusan cerai yang ditetapkan oleh negara (dalam hal ini pengadilan). Kemudian peneliti dan pihak gereja dapat saja mengajukan usul untuk melakukan amandemen Undang-undang Perceraian (dan juga Undang-undang Perkawinan) kepada Mahkamah Konstitusi sehubungan unsur kekekalan pernikahan dalam kekristenan dan dalam Alkitab. Namun demikian oleh sebab adanya teori kepastian hukum Nasional yang menggunakan teks 
Rm. 13:1-7 (sebagaimana yang telah diutarakan pada bagian 2.2.2.), dan yang dibatalkan dalam keputusan cerai tersebut adalah surat (akta) perkawinan yang diterbitkan oleh Dinas Kependudukan dan Catatan Sipil (Disdukcapil), maka gereja hampir tidak memiliki kapastitas untuk mengintervensi keputusan negara tersebut. Ditambah lagi apabila pasutri tersebut memang sudah tidak mau lagi untuk tinggal di dalam satu rumah sejak perselisihan terjadi. Jangankan untuk menanggulangi perceraian, untuk melakukan perkunjungan konseling saja sudah sulit, sebab salah satu atau kedua pihak dari pasutri tersebut sudah sulit diketahui domisili atau alamat tempat tinggalnya (berpindah-pindah) dan atau mereka tidak bersedia atau tidak mau urusan rumahtangganya diintervensi oleh pihak gereja.

4. Adalah suatu pekerjaan yang sangat sulit bagi gereja (dalam hal ini pastor, pendeta, penatua, imam kaum penghayat kepercayaan) untuk melakukan percakapan konseling perkawinan apabila situasi perselisihan pasutri sudah berada pada tahap melakukan tindakan kekerasan fisik. Hal ini dapat saja akan membuat salah-satu pihak pasutri tidak bersedia untuk menjalani bimbingan konseling, baik pihak yang menjadi pelaku kekerasan fisik (mungkin oleh rasa malu); apalagi pihak yang menjadi korban kekerasan fisik (mungkin oleh pengalaman trauma). Tidak jarang usaha percakapan konseling dalam penanggulangan perceraian mengalami jalan buntu dan akhirnya bercerai oleh sebab ketidakhadiran salah satu pasutri dalam menjalani konseling tersebut. Oleh sebab itu bimbingan perkawinan sangat dianjurkan untuk dilakukan pada usia lima tahun perkawinan.

Dari seluruh penjelasan di atas peneliti perlu memberikan beberapa pokok saran yang patut untuk dipertimbangkan, yaitu: pertama, modul konseling pernikahan tersebut sebaiknya ditujukan kepada pasangan yang akan melangsungkan pernikahan, atau lazim disebut Konseling Pra-Nikah. Sebab pada dasarnya dari setiap putusan perceraian yang terjadi, pasangan terebut bukanlah pasangan yang seimbang dalam karakter, sikap dan tanggungjawab dalam membangun rumahtangga (bnd. 2Kor. 6:14). Kedua, modul konseling pra-nikah tersebut dapat memuat pembahasan tentang tugas dan tanggung jawab detil seorang suami dan penjelasan maksud dan tujuan dari tanggungjawab tersebut serta resiko yang harus diketahui dan dipahami oleh kedua belah pihak bila hal-hal tentang tanggungjawab tersebut tidak dipenuhi. Ketiga, modul tersebut berisi checking list tentang pemenuhan tanggungjawab calon pasutri dan juga orangtua atau wali masing-masing calon pasutri, yang telah mereka lakukan enam bulan sebelum pernikahan. Checking list itu sendiri sebaiknya diisi dengan jujur oleh masing-masing pihak. Dengan demikian masing-masing orangtua atau wali calon pasutri memiliki peran sangat besar terhadap kelangsungan rumahtangga anaknya. Dari titik ini dapat juga dijadikan indikator tanggungjawab orangtua dalam mendidikan dan mengawasi karakter dan sikap anaknya masing-masing. Sebab hal tersebut berkaitan langsung dengan resiko ketidakharmonisan atau bahkan perceraian rumahtangga anak mereka sendiri.

Keempat, dalam rencana penyusunan modul konseling pernikahan, perlu juga dipertimbangkan untuk memasukkan unsur yang bentuknya mengikat kedua pihak pasutri dalam pembinaan pasutri pasca pernikahan, dalam hal ini mewajibkan mereka untuk menjadi anggota komunitas atau persekutuan masing-masing untuk kaum bapak dan ibu, khususnya bila para pelayan rohani telah mendengar pasutri tersebut sedang menghadapi konflik rumahtangga. Kelima, sehubungan dengan pokok perselisihan dan pertengkaran tersebut, maka dalam penyusunan modul penanggulangan yang akan dikembangkan sangat perlu untuk memuat materi bimbingan tentang pengendalian diri dalam menahan emosi dan juga tentang komunikasi yang memadai dalam masa berpacaran atau dalam pelaksanaan bimbingan pranikah. Keenam, sedangkan mengenai adanya penyakit yang 
diidap salah satu pihak pasutri baik penyakit medis maupun unsur psikologis (mis. impotensi), maka pada modul yang akan dikembangkan kemudian perlu dimasukkan tentang perlunya dorongan dan dukungan dari pasangannya untuk ikut pemendampingi pasangannya tersebut dalam menjalani terapi medis dan psikologis, secara khusus tentang sikap penerimaan situasi dan keadaan pasangannya yang sedang mengidap penyakit tersebut atas nama dan di dalam cinta kasih yang murni yang datang dari TUHAN.

\section{Rujukan}

Arikunto, Suharsimi. Prosedur Penelitian, Suatu Pendekatan Praktik. Jakarta: Rineka Cipta, 2010.

Charlton, T. Latin Dictrionary. Great Britain: Oxford University, 1980.

Clarke, Lynda | Berrington, Ann. Socio-Demographic Predictors of Divorce. London,: University of Southampton, 1999.

Hasting, James. Dictionary of The Bible Vol. III. New York: Charles Scribner's Son, 1950.

Levinger, George | Moles, Oliver C. Divorce and Separation, Context, Causes and Consequences. New York: Bank Books, 1979.

Manalu, Parluhutan. Pernikahan. Yogyakarta: Andi, 2015.

Prawiroharmidjojo, R. Soetodjo, dan Saefuddin, Aziz. Hukum Orang dan Keluarga. Bandung: Alumni, 1986.

Roberti, Franscesco Cardinal. Dictionary of Moral Theology. USA: Newman, 1962.

Simanjuntak, P. N. H. Pokok-pokok Hukum Perdata Indonesia. Jakarta: Pustaka Djambatan, 2007.

Soekanto, Soerjono. Sosiologi Keluarga: Tentang Ikhwal Keluarga, Remaja dan Anak. Jakarta: Rineka Cipta, 1990.

Subekti. Pokok-pokok Hukum Perdata. Jakarta: Intermasa, 1985.

Stanley, Scott M., | Markman, Howard J., "Preventing Marital Distress Through Communication And Conflict Management Training: A Four And Five Year FollowUp", Journal of Consulting and Clinical Psychology, Vol. 62, No. 1, 1993, hlm. 70-77.

Tim Penyusun Kamus Pusat Pembinaan dan Pengembangan Bahasa. Kamus Besar Bahasa Indonesia Edisi Kedua. Jakarta: Balai Pustaka, 1997.

Jurnal

Jurnal Hukum Universitas Brawijaya, http://hukum. studentjournal.ub.ac.id/ index.php/hukum/article/view/2253/1402 Tahun 2011, diakses tgl. 14 Juli 2018 pkl. 17:32.

Wawancara

Aser Limbong, wawancara oleh Tim Peneliti, Tarutung, Indonesia, 04 Pebruari 2018. 